\title{
Gender Differences In Academic Ethics With Recommendations For Curricular Change
}

Virginia M. Miori, St. Joseph's University, USA

Kelly A. Doyle, Abington School District, USA

Kathleen Campbell, St. Joseph's University, USA

\begin{abstract}
An extensive study has been performed on the importance of building ethical principles into secondary school and college curricula. In published surveys, females are almost universally found to be more ethical, but experience tells us females lag behind males in their ability to maintain and act upon their convictions in the workplace. We examined these issues by administering a survey on academic ethics to an undergraduate business school population, focusing heavily on gender differences. Careful analysis of survey results using one-way ANOVA, the Tukey-Kramer procedure, and two-way ANOVA procedures provided an understanding of differences in ethical beliefs and ethical behaviors based on gender and other demographic characterizations. Predictive analysis was completed using logistic regression and discrete choice modeling to determine the likelihood of ethical behavior in the future and evolution of ethical beliefs. The accumulated results of the analyses were used to guide the authors in the development of a strong and pervasive ethics-based curriculum for secondary schools and universities. We have combined elements of classroom instruction, technology, active learning, games and extracurricular activities to embed ethical concepts and particularly encourage strength in convictions across the entire curricula.
\end{abstract}

Keywords: Ethics-based curriculum; secondary education; ANOVA; Ethics

\section{INTRODUCTION}

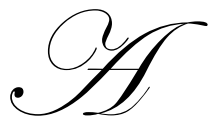

s academicians, we have observed sufficient questionable behavior by students to cast doubt on the state of academic ethics. We are faced with what we perceive to be declining ethical standards on a daily basis. These observations become more disturbing in light of the seemingly continuous revelations about the declining state of ethics in the corporate world. We not only learn of intentional deceptions to boost stock values, but we learn of outright deficiencies giving a clear picture of the state of ethics in the corporate world.

"I see no hope for the future of our people if they are dependent on the frivolous youth of today, for certainly all youth are reckless beyond words. When I was a boy, we were taught to be discreet and respectful of elders, but the present youth are exceedingly wise and impatient of restraint." [http://thinkexist.com] We've all identified with this quotation at one time or another, yet recall this was said by the Greek poet, Hesiod, in the $8^{\text {th }}$ century BC, when Hesiod is believed to have lived. The future was not lost then and it is not lost now. We are, however, called to address our concerns and enhance the quality and pervasiveness of ethics education in our secondary schools, colleges and universities.

An extensive study has already been completed on the importance of building ethical principles into secondary school and college curricula. Particular focus has been placed on curricula in the areas of medicine, biology, criminal justice and business. The proposals to date generally lack an emphasis on instilling ethical 
principles at an earlier age. In addition, in published surveys, females are almost universally found to act more ethically, but experience tells us females lag behind males in their ability to maintain and act upon their convictions in the workplace.

This research was initiated in an effort to enhance ethics education in secondary schools and universities, but with a primary emphasis on reaching young women. We began by developing a survey exploring academic ethics and the nuances present in academic ethics. The survey was administered to the undergraduate freshman and sophomore population at St. Joseph's University, a Catholic Jesuit university in Philadelphia, PA. Additional data were collected in the form of survey results published by the Josephson Institute Center for Youth Ethics (JICYE) (Josephson, 2008), who conduct a survey of high school students in the area of ethics every two years.

We examined these issues in our survey by focusing heavily on gender differences. Careful analysis of survey results using one-way ANOVA, the Tukey-Kramer, and two-way ANOVA procedures provided an understanding of differences in ethical beliefs and ethical behaviors based on gender and other demographic characterizations. Predictive analysis was completed using logistic regression and discrete choice modeling to determine the likelihood of ethical behavior in the future and evolution of ethical beliefs. The accumulated results of the analyses were used to guide the authors in the development of a strong and pervasive ethics-based curriculum for secondary schools and universities. We have combined elements of classroom instruction, technology, active learning, games, and extracurricular activities to embed ethical concepts and particularly encourage strength in convictions, across entire curricula.

In this paper, we first examine the state of ethics education, using our own and other surveys administered to college and high school students. A thorough statistical analysis of our survey results is presented in the data analysis section, along with findings presented by JICYE. We summarize our research findings and finally present a unified curriculum in the interest of addressing documented gaps in ethics education.

\section{BACKGROUND}

Development and assessment of curricula has been a popular area of research in the last decade. The main purpose of this research is to improve, develop and adapt existing curricula to address the continually growing ethical gaps evidenced in society. Though many college programs have been studied, limited research exists on the creation of ethics-based curricula in secondary schools. This literature review highlights the areas most commonly examined as well as research completed in the area of character education. Character education, which typically addresses adolescents, provides significant carry over into our recommendations on secondary school curricula.

The Josephson Institute Center for Youth Ethics conducts a survey of high school students in the area of ethics (The Ethics of American Youth). The survey has been conducted every two years since 1998 with questions addressing stealing, lying and cheating. The questions are available upon request to the authors. The Josephson Institute has also concluded that unethical adolescents carry that behavior into the future and become unethical adults (Josephson, 2008).

Character education is often equated with ethics education and in fact extends beyond the typical goals of ethics education. The goal of character education is not only to ingrain an understanding of the meaning and rules of ethics within certain sectors, but also to ingrain characteristics in individuals that inspire vision exclusive of exploitation. The concept of forgiveness is seen as integral to this approach (Rodden, 2004). Critical thinking skills and their contribution to character education (Wright, 2002) and citizenship(Hoge, 2002) within the teaching of social studies (Milson, 2002), teaching children social skills (McArthur,2002) as well as the use of literature in character education (Edgington, 2002) have been explored. Character education for cyberspace in the interest of creating good internet citizens (Wilson and Chu, 2002), and responding to the direct needs of children (Noddings, 2005) are also important areas of character education.

Studies of ethics education have been completed in many areas within university and specialized curricula. An increasing interest in augmenting public health curricula with ethics education led to a survey of schools of public health in the United States between 1996 and 1997 (Coughlin et al, 1999). Little was known about the degree 
of ethics instruction in schools of public health, therefore research was completed in order to determine the state of ethics within these curricula.

The seeming crisis in news reporting prompted study with the area of a Media Ethics program. Pre- and post-education surveys were performed on Media Ethics students between 2001 and 2004 (Plaisance, 2007). The research was conducted to address a dearth of examination of this university-level educational area.

Ethics education in medical schools has been very closely examined due to the obvious and extraordinary need for ethical medical professionals. Researchers began with the question of understanding whether medical schools have produced ethical doctors (Campbell et al, 2007) and what the current standing is of ethics in medical programs (Mattick and Bligh, 2006). The need for new codes of ethics in nursing was established through discussions with nursing students in Finland (Numminen, 2009). Examination of the teaching of these codes of ethics has also been lacking. The ethics associated with animal testing also falls into this category, under the umbrella of medical and scientific research (Andrew and Robottom, 2001). Evaluation of the reasons for chosen responses to questions of medical ethics has also been performed (Goldie et al, 2004) in an effort to strengthen teaching and learning.

The role of ethics in criminal justice curricula had also recently been examined (Rhineberger-Dunn and Mullins, 2008). This research looked not only at ethics education and pedagogy within academic institutions, but also the extent to which ethics education and conversations extended into the professional world of criminal justice.

The effectiveness of ethics education in business schools has been examined by reviewing curricula as well as through empirical study (Ritter, 2006). The purpose of this research was to determine whether we could effectively teach business ethics. Gender differences were found to be significant with females showing an improved moral awareness as well as improved decision-making processes. Gender focus has been examined from different perspectives, including the application of feminist pedagogy to more effectively embed ethical values into business school students at a college or university level (Rabouin, 1996).

Within a business school setting, with classes of undergraduate and graduate students, an ethics exercise was performed (Boehrer, 2003). It specifically focused on the ethics of resigning in the wake of ineffective leadership in government and political positions. Students began to see how pressures from family and colleagues could be applied in an effort to dissuade an individual from following their own ethical convictions.

Reassessing the domain of business ethics was completed in order to identify gaps in ethics education (Crane and Matten, 2004). These included gaps created by increased globalization, recent business scandals, geographic peculiarities and stakeholder requirements. The inclusion of a required ethics class in an accounting program as a prerequisite to the CPA exam was studies in Texas (Hurtt and Thomas, 2008). The intent of the research was course design recommendations.

Ethics education in European business schools is being studied to enhance internationalization in business and academics. A study at a British university tried to empirically gage the students' level of moral awareness to determine their readiness for ethics education and the appropriate way to design a curriculum in which ethics education would be emphasized (Lowry, 2003). University education in Spain is presented as a case study, resulting is the realization that integrating ethics into education is still not well defined (Escámez et al, 2008).

\section{SURVEY ADMINISTRATION}

The survey was determined by the St. Joseph's University (SJU) internal review board (IRB) to be exempt. It was administered using the Survey Monkey website with the consent and link to the survey being distributed by email to freshmen and sophomores at SJU. The survey is contained in available upon request from the authors and was distributed over a one and a half year period in 2009 and 2010. Incentives in the form of extra credit points were offered to students to encourage them to complete the survey. Students were also offered extra credit points for engaging their friends in the completion of the survey. 
Respondents were first asked a series of demographic questions regarding their secondary education, education of parents and work responsibilities. The questions then turned to their overall view of the level of academic ethics demonstrated by their classmates. The final survey questions provided scenarios, asking the students to explore their own definitions of ethical and unethical behavior in an academic setting.

In total, approximately 475 students completed the survey. Of these, only one student appeared to deliberately provide falsified responses. This became obvious as the student answered all survey questions with the last possible choice. Due to the obvious disregard for the intent of the survey, this student's survey response was eliminated from the overall pool of responses. Five students provided incomplete survey responses and were also removed from the pool of responses due to missing data. The remaining responses were retained in the data. Responses were coded in Survey Monkey and downloaded for use in JMP statistical software.

\section{DATA ANALYSIS}

\section{Assumptions}

The primary method of data analysis was Analysis of Variance, which falls into the category of a linear model. Three assumptions are important in the case of linear models. The first is independence of responses. We have achieved this through the survey administration method. Students were solicited at random within the sophomore class at St. Joseph's University.

The second assumption is the normality of the distribution of residuals. This assumption is robust, particularly with large samples. Therefore, with a sample size of 475 , we may rely on the Central Limit Theorem to support the assumption of normality. Failing normality, the Kruskal-Wallis test and the Friedman test provide nonparametric alternatives to the F-test in one-way ANOVA.

The third assumption is that of equal variance, or homoscedasticity, within groups of data. One-way ANOVA results are not terribly sensitive to violations of homoscedasticity, particularly in the case of equal or nearly equal sample sizes. Our primary population distinction is based on gender, of which $48.4 \%$ are male and $51.5 \%$ female. This enables us to assume equal variance. In order to support this assumption in other population designations, we sample our data to ensure equal sample sizes.

The logistic regression models require the response variable to be binary and the explanatory variables may be continuous, categorical or binary in nature. The logistic regression model then relates the probability of an occurrence (such as instance of gender) of an event to the specified explanatory variables. Logistic regression does not share all of the assumptions of the ANOVA, only that observations are independent and the explanatory variables should be linearly related to the logit of the response variable.

\section{Tools}

The analyses performed in this research were completed using Excel, Minitab and SAS JMP software products. The variation in software tools was due to the strengths and capabilities of the products. Initial data examination and cleansing were done in Excel. Examination of the entire body of sample survey data using Oneway ANOVA was performed in SAS JMP due to the streamlined ability to run many ANOVAs in a single command screen. JMP was also used to create random subsets of the data for further analysis using Two-way ANOVA. The Two-Way ANOVA procedures were ultimately completed in Minitab as were the logistic regression models.

\section{Results}

The evaluation of the ethics survey data required the completion of over 150 ANOVA procedures and a dozen logistic regressions. We begin with the discussion of one-way analysis of variance procedures. The overall survey data was stratified into samples representing various populations, each of which distinction served as a factor in a series of ANOVAs. These population distinctions include: gender, secondary school type, parents' education, 
reported GPA, hours worked per week, ethics education in secondary school, and number of courses emphasizing ethics in secondary school.

The response variables under consideration included a number of the factors above as well as responses to a series of questions regarding strength of ethical convictions. These ranged from questions examining the ethics of scenarios presented to questions examining the willingness to compromise ethics-based on time management issues, quality of instruction and degree of punishment associated with being caught.

Due to the nature of behavioral study, the complexities of human choice, and biases associated with reporting these choices, we know that significance levels need not be particularly small. As a result, the authors had designated an alpha value of .15 prior to completion of these analyses. In many cases, the significance was below .05 , making the results even stronger. These results are designated by an asterisk (*).

The complete ANOVA results are available upon request from the authors, with the most relevant of these results presented in Tables 1,2 and 3. These tables provide the explanatory and response variables, the categories in which different means were found, the values of these means (in parentheses) and the question type with possible responses.

In Table 1, the findings showed a significant gender difference in ethical standards. Females were found to be of equal or greater ethical standards than males and, in many cases, their ethical standards were clearly higher. We also found that ethics education is limited in secondary schools, with significant differences existing between Catholic-based schools and public schools. One very interesting finding was that over $80 \%$ of individuals see themselves as being more ethical than their classmates. This leads us to the conclusion that ethical standards are individually defined and clearly quite subjective. Students consider themselves to be quite ethical, though perhaps not by any particular social standard, and certainly not by any established academic standard.

Table 1: Results of One-way ANOVAs

\begin{tabular}{|c|c|c|c|c|}
\hline Response Variable & Explanatory Variable & $\begin{array}{c}\text { Comparison } \\
\text { Category } 1\end{array}$ & $\begin{array}{c}\text { Comparison } \\
\text { Category } 2\end{array}$ & Question Type \\
\hline \multirow[t]{2}{*}{$\begin{array}{l}\text { Ethics Taught in } \\
\text { Secondary School? }\end{array}$} & \multirow{2}{*}{$\begin{array}{l}\text { Secondary School Type } \\
\text { Public (48\%) } \\
\text { Parochial (11\%) } \\
\text { Private Catholic }(37 \%)\end{array}$} & $\begin{array}{l}\text { Public schools } \\
(13 \%)\end{array}$ & $\begin{array}{l}\text { Parochial Schools } \\
(34 \%)\end{array}$ & \multirow{2}{*}{$\begin{array}{l}\text { Binary Response } \\
1=Y e s \\
2=N o\end{array}$} \\
\hline & & $\begin{array}{l}\text { Public schools } \\
(13 \%)\end{array}$ & $\begin{array}{l}\text { Private Catholic } \\
(41 \%)\end{array}$ & \\
\hline $\begin{array}{l}\text { Which is the more ethical } \\
\text { gender? }\end{array}$ & $\begin{array}{l}\text { Gender } \\
\text { Male }(52 \%) \\
\text { Female }(48 \%)\end{array}$ & Male $(10 \%)$ & Female $(45 \%)$ & $\begin{array}{l}\text { Multiple choice } \\
1=\text { Male } \\
2=\text { Female } \\
3=\text { Neither }\end{array}$ \\
\hline $\begin{array}{l}\text { Do you consider yourself } \\
\text { more ethical than your } \\
\text { classmates? }\end{array}$ & $\begin{array}{l}\text { Gender } \\
\text { Male }(52 \%) \\
\text { Female }(48 \%) \\
\end{array}$ & Male $(80 \%)$ & Female $(83 \%)$ & Binary Response \\
\hline
\end{tabular}

Table 2 highlighted the question of whether an individual's ethics might be compromised if they would not be caught cheating. We again noted a significant gender gap, with females being less likely to compromise their ideals. An addition, gap was identified between lower and higher GPAs as well as students who work being less likely to compromise their ideals than those who don't. Students who work full-time were more consistent than those who worked part-time. This analysis calls the effectiveness of ethics education strongly into question. Are we simply providing the students with a road map and not embedding character traits?

Students are able to justify unethical behavior and make ethical choices based on the severity of discipline. These further emphasize the ineffectiveness of the limited ethics education provided in secondary schools. Table 3 shows that parochial school students were more likely to justify unethical behavior, while public school students were significantly less likely. The gender gap continues to exist with females displaying higher ethical standards. 
Table 2: Results of One-way ANOVAs

\begin{tabular}{|c|c|c|c|c|}
\hline Response Variable & Explanatory Variable & $\begin{array}{l}\text { Comparison } \\
\text { Category } 1 \\
\end{array}$ & $\begin{array}{l}\text { Comparison } \\
\text { Category } 2 \\
\end{array}$ & Question Type \\
\hline \multirow{12}{*}{$\begin{array}{l}\text { *Would you engage in } \\
\text { unethical behavior if you } \\
\text { knew you would not be } \\
\text { caught? }\end{array}$} & $\begin{array}{l}\text { Gender } \\
\text { Male }(52 \%) \\
\text { Female }(48 \%)\end{array}$ & Male (3.31) & Female (3.59) & \multirow[t]{12}{*}{$\begin{array}{l}\text { Sliding Scale } \\
1=\text { always } \\
5=\text { never }\end{array}$} \\
\hline & \multirow{5}{*}{$\begin{array}{l}\text { GPA } \\
1=\text { not a college student } \\
2=\text { unknown } \\
3=\text { under } 2.5 \\
4=2.5 \text { to } 3.0 \\
5=3.0 \text { to } 3.5 \\
6=3.5 \text { to } 4.0\end{array}$} & Under $2.5(2.65)$ & 2.5 to $3.0(3.45)$ & \\
\hline & & Under $2.5(2.65)$ & 3.0 to $3.5(3.40)$ & \\
\hline & & Under $2.5(2.65)$ & 3.5 to $4.0(3.62)$ & \\
\hline & & Under $2.5(2.75)$ & $3.0-3.5(2.13)$ & \\
\hline & & Under $2.5(2.75)$ & $3.5-4.0(1.99)$ & \\
\hline & \multirow{6}{*}{$\begin{array}{l}\text { Hours Worked } \\
1=\text { not employed } \\
2=1 \text { to } 15 \text { hours } / w k \\
3=15 \text { to } 30 \text { hours } / w k \\
4=30 \text { plus hours } / w k\end{array}$} & $\begin{array}{l}\text { Not employed } \\
(3.34)\end{array}$ & $\begin{array}{l}30 \text { plus hours/wk } \\
(3.97)\end{array}$ & \\
\hline & & $\begin{array}{l}1 \text { to } 15 \text { hours/wk } \\
(3.47)\end{array}$ & $\begin{array}{l}30 \text { plus hours/wk } \\
(3.97)\end{array}$ & \\
\hline & & $\begin{array}{l}15 \text { to } 30 \text { hours/wk } \\
(3.43)\end{array}$ & $\begin{array}{l}30 \text { plus hours/wk } \\
(3.97)\end{array}$ & \\
\hline & & Under $2.5(1.75)$ & 3.0 to $3.5(1.96)$ & \\
\hline & & Under $2.5(1.75)$ & 3.5 to $4.0(1.95)$ & \\
\hline & & 0 courses $(1.97)$ & 4 to 6 courses $(1.87)$ & \\
\hline
\end{tabular}

Table 3: Results of One-way ANOVAs

\begin{tabular}{|c|c|c|c|c|}
\hline Response Variable & Explanatory Variable & $\begin{array}{c}\text { Comparison } \\
\text { Category } 1\end{array}$ & Comparison Category 2 & Question Type \\
\hline \multirow{4}{*}{$\begin{array}{l}\text { *Can unethical behavior } \\
\text { be justified under certain } \\
\text { circumstances? }\end{array}$} & Secondary School Type & Parochial (1.68) & Private Catholic (1.31) & \multirow{4}{*}{$\begin{array}{l}\text { Binary Response } \\
1=y e s \\
2=n o\end{array}$} \\
\hline & Public (48\%) & Parochial (1.68) & Public (1.46) & \\
\hline & $\begin{array}{l}\text { Parochial }(11 \%) \\
\text { Private Catholic (37\%) }\end{array}$ & Public (1.46) & Private Catholic (1.31) & \\
\hline & $\begin{array}{l}\text { Gender } \\
\text { Male }(52 \%) \\
\text { Female }(48 \%)\end{array}$ & Male (1.38) & Female (1.49) & \\
\hline $\begin{array}{l}\text { *Would the severity of } \\
\text { discipline influence your } \\
\text { decision to engage in } \\
\text { unethical behavior? }\end{array}$ & $\begin{array}{l}\text { Gender } \\
\text { Male }(52 \%) \\
\text { Female }(48 \%)\end{array}$ & Male (1.28) & Female (1.21) & $\begin{array}{l}\text { Binary Response } \\
1=Y e s \\
2=N o\end{array}$ \\
\hline
\end{tabular}

Clearly, many significant results were found. The most important implications of the results highlighted the difference between male and female students. Females have almost universally higher ethical standards than males, a finding which is also echoed in the Josephson Institute Center for Youth Ethics survey.

Another significant finding was based on secondary school type. More ethics courses are taught in private Catholic academies, an average of three, than any other school type, yet these same academies displayed a weaker sense of ethics than the public schools in which one course focused on ethics on average.

The two-way ANOVAs examined interactions that might occur between two of the factors explored in the one-way ANOVAs. These specifically focused on gender and secondary school type as factors. These two variables were selected based on their demonstrated significance in the one-way ANOVAs. The response variables included specification of the more ethical gender, observed instances of cheating by female students, observed instances of cheating by male students, ethics of scenarios, change in personal ethical standards, and questions examining the willingness to compromise ethics. The interactions examined were of less significance that the oneway ANOVA results, with the primary focus again being on type of secondary school and gender. These results are presented in Table 4. 
Table 4: Results of Two-Way ANOVAs

\begin{tabular}{|l|c|c|}
\hline \multicolumn{1}{|c|}{ Response Variable } & Explanatory Variables & Significance of Interaction \\
\hline Is it ethical to copy a classmate's test? & $\begin{array}{c}\text { School Type } \\
\text { Gender }\end{array}$ & $71 \%$ significance \\
\hline Is it ethical to discuss an assignment with a peer? & $\begin{array}{c}\text { School Type } \\
\text { Gender }\end{array}$ & $78 \%$ significance \\
\hline $\begin{array}{l}\text { Would the severity of discipline influence your decision to } \\
\text { engage in unethical behavior? }\end{array}$ & $\begin{array}{c}\text { School Type } \\
\text { Gender }\end{array}$ & $\begin{array}{c}\text { School Type } \\
\text { Gender }\end{array}$ \\
\hline $\begin{array}{l}\text { Is cheating justified if you are treated improperly by an } \\
\text { instructor? }\end{array}$ & & $91 \%$ significance \\
\hline
\end{tabular}

The final area of analysis was logistic regression. The logistic regressions were performed to determine if particular attitudes and behaviors might allow us to predict the gender of the student. The value in determining this is establishing whether gender-based ethics curricula might be developed for secondary schools and what those curricula might include. The logistics regressions provided likelihoods that particular responses to selected questions could isolate student behavior by gender. The results of the logistic regressions show that responses to the following questions were significant indicators of gender:

- $\quad$ Is it ethical to copy a classmate's test?

- Is it ethical to copy a classmate's homework?

- Is it ethical to obtain advanced test information?

- $\quad$ Is it ethical to copy a published document?

- Is cheating justified if you have a deadline?

- $\quad$ Is cheating justified if you have an athletic event to attend?

- $\quad$ Is cheating justified if you are treated improperly by an instructor?

- Would you engage in unethical academic behavior if the outcome were a warning?

- Would you engage in unethical academic behavior if letter grade reduction?

\section{RESEARCH IMPLICATIONS}

In published surveys and our own survey, females are almost universally found to be more ethical, but anecdotally lag behind males in their ability to carry convictions into the workplace. We've also learned that teaching ethics in a classroom may not be sufficient to help students develop true, value based ethical standards.

We must instill ethical principles that serve our children as they grow and progress through academic and professional settings. It's critically important that we address ethics in many different courses and in many different ways. Our students must be encouraged to explore their own feelings on the subject and examine the legacy they would like to create. In particular, we also recognize a significant resource in our young women. Women are significant resources in the workplace and have demonstrated high ethical standards, based on this research, it is imperative that educators nurture and encourage strength of character and voice in the workplace. It was with that end in mind that this research was initiated.

\section{CURRICULAR RECOMMENDATIONS}

The final section of our paper focuses on curricular recommendations as the natural outgrowth of our research. As Thomas Jefferson said, "If the children are untaught, their ignorance and vices will in future life cost us much dearer in their consequences than it would have done in their correction by a good education." [http://thinkexist.com]

Research related to curriculum development indicates that integration across the curriculum, engaging students in active learning experiences, the use of technology, and attention to the needs of adolescent learners will enhance student learning. Research specific to ethics instruction further recommends that ethics be addressed on a school-wide basis. The recommendations set forth here adhere to the above-referenced concepts and are 
comprehensive, including an ethics course and integration of ethics instruction across the curriculum and extracurricular activities, which relate to content, delivery and monitoring the implementation of an effective ethics program for adolescent and young adult learners.

A specific course focusing on ethics should be offered at the high school and collegiate levels. The current study indicates that only $25 \%$ of this population participated in an ethics course at the high school level. This ethics course should be mandatory for all students, preferably in the first year of instruction in the school. Students entering the school after the traditional entry-year should also be required to enroll in the course. For example, in a typical high school setting, students in grade 9 are in their first year in the building and should be scheduled for ethics. However, any student entering the school as a sophomore, junior, or senior, should also be scheduled into the ethics course. Such cross-grade level scheduling is not uncommon in high school and college settings. This requirement will ensure that all students are exposed to the basic concepts and principles, the foundation upon which the school-wide ethics integration will be based.

The content of this designated ethics course would vary from one school district to the next, from one college or university to the next. While the content will vary, however, there are many frameworks currently available from which course designers can draw information. Most strive to incorporate a number of core principles, including but not limited to fairness, honesty, integrity, pursuit of excellence, responsibility, cooperation, and respect (Lickona, 2004; Partnership for $21^{\text {st }}$ Century Skills, 2007). Other principles identified for ethics instruction include leadership, flexibility, courage, loyalty, justice, hope, and love (Likona, 2004). Some educators go so far as to say an overhaul of the current curriculum is necessary to help students achieve $21^{\text {st }}$ century success. This would include educating students in the aforementioned principles of respect, cooperation and responsibility, along with "an appreciation of our common humanity." More than one educational organization (NEA, 2010; Partnership for $21^{\text {st }}$ Century Skills, 2007) recommend including a sense of this responsibility and humanity as related to the global community, not merely the students' own local community. They recommend addressing an "international awareness, which includes the understanding that local and national events can have international implications.... and the recognition that one person's actions can affect others beyond one's own borders (NEA, 2010). Furthermore, they recommend focusing leadership and responsibility instruction on "demonstrating integrity and ethical behavior and acting responsibly with the interests of the larger community in mind" (Partnership for $21^{\text {st }}$ Century Skills, 2007).

Secondly, curriculum research supports curricular integration as a way to reinforce concepts for students (Moore, 2008, and Rhodes, 2003). The same may be true for ethics instruction. However, 48\% of students participating in the current study reported that ethics was integrated in only one to three courses over the course of their high school education. This lack of ethics instruction and integration into various courses may account for some of the surprising survey results, as related to students' perceptions of unethical versus moderately unethical behaviors.

Curricular integration would begin with the general ethics course recommended above. As with most curricular integration initiatives (Moore, 2008), this integration should be required in all courses, including those traditionally referred to as "major" courses, as well as electives. It is recommended that this integration is a required component of the curriculum. Allowing teachers to implement this integration on an "as-needed" or "asappropriate" basis may lead to a less than consistent implementation. To further ensure consistent implementation of the ethics integration, several administrative components are recommended. First, the integration should be a documented component of the curriculum. In most school districts today, courses are taught according to a written document, sometimes called a "planned course of study." The identified ethics principles, as well as appropriate and required resources for their instruction, should be included in the planned course of study that is the official document driving instruction. Secondly, in buildings where teachers are required to submit lesson plans, teachers should be required to note in their lesson plans which lesson are related to ethics integration. The notation may vary depending on the administrators' and/or teachers' preferences. Examples include highlighting the lesson in a different color, listing ethics-related lessons separately, storing lesson plans in a data warehouse system and running reports for ethics-based lessons. Third, classroom observations conducted by administrators will serve as a tool for enduring implementation of the curricular integration. Administrators visit a classroom and conduct a formal observation, having chosen the lesson specifically due to the nature of the ethics integration, as indicated by the 
teacher on the above-referenced lesson plans. A shorter type of classroom observation, a walk-through, is another tool for assessing effective implementation of the ethics integration initiative. Lastly, administrative support for ethics integration occurs with appropriate professional development. Professional development sets the stage and provides teachers with both content and pedagogical knowledge necessary to implement the ethics instruction in a way that actively engages students in their own learning. To be effective, the professional development should be ongoing, collaborative, and include opportunities for reflection. (Perkins-Gough, 2002).

Researchers (Moore, 2008; Rhodes, 2003) recommend curriculum integration as a vehicle for improving student achievement and understanding of concepts. Such curricular integration takes many forms. In one model, each principle from the ethics course is assigned to one or more curriculum departments. Every course taught in the department incorporates lessons related to that principle. The integration is systematic in nature in that each department selects one or two principles; all principles are addressed across the entire curriculum, but not all principles are taught in all subjects. The English Department, for example, may select the principle of "fairness" because it is woven throughout many classic and contemporary pieces of literature. In this model of integration, the English teachers may integrate this trait into the teaching of novels such as To Kill a Mockingbird. One of the main characters, Atticus Finch, holds this trait closely to his heart and lives both his professional and personal lives accordingly. The Science Department may choose to integrate the principle of "responsibility." Using textbooks or supplemental materials, such as scientific journals, biographies, and/or current newspaper or magazine articles, teachers provide illustrative examples of the need for responsibility in science, including research endeavors and the consequences of ignoring this trait in the science fields. This inter-departmental integration extends to departments traditionally considered "non-academic," as well. For example, Physical Education Department members have numerous opportunities to integrate the principle of cooperation into their instruction, particularly and most obviously with games where teams are used. This type of integration ensures that all principles are addressed at one point or another in a given academic year.

Another model of curricular integration of ethic principles is not discipline-specific. Rather, all principles may be threaded through all subjects. Each department may select any principle(s) and integrate as deemed appropriate by the teachers and/or administrators. In this case, while the aforementioned English Department members focused their instruction on honesty with To Kill a Mockingbird, they may additionally focus on pursuit of excellence with another novel or piece of non-fiction literature and on respect while teaching yet another selection. The Science department may also focus on honesty and respect. In this model, there is overlap amongst the curricular departments; students are likely to be exposed to the same principles in more than one course. Both models have advantages and disadvantages. Administrators and teachers should collaboratively identify which model to follow and do so with integrity to ensure students have maximum exposure to the principles identified as essential for a given institution's ethics integration.

In order to most effectively teach ethics to adolescents and young adults, both in the independent course and via curriculum integration, educators must also consider how $21^{\text {st }}$ century students learn best. According to the U. S. Department of Education's "Partnership for $21^{\text {st }}$ Century Skills" organization, both instructional strategies and the learning environment impact the effectiveness of a curricular program. Differentiated instruction is essential, especially based on students' learning styles. Additionally, lessons should be "relevant to student experiences, and call for authentic application of knowledge and understanding" (Loepp, 1999; Moore, 2008; NCREL, 2005). Teachers can design (or use existing available resources) situations in which students role play and then discuss the ethics of various decisions. For example, students watch a video clip and then discuss what they would do if they received the answers to a test in advance (Annenberg Foundation) or participate in role playing of cybercrime activities (Socrates Institute). Role playing is critical as the first time a student faces a decision-making situation based on ethics should not be "for real;" practice opportunities afford students time to discuss, consider consequences or all responses, and reflect on those consequences and decisions. Furthermore, units of instruction should include lessons that progress from teacher-led to self-directed, thus creating a learning environment that actively engages students and places more responsibility for the learning process on students themselves. For example, in the ethics course itself, the teacher can lead book discussions akin to a book club, modeling for students the types of questions and issues generally discussed in such a setting. Then, she gradually releases her role as leader of the book club by dividing the class into groups and having each group serve as its own individual book club, each focusing on one of the ethics principles. 
Collaboration, student engagement, and project-based learning experiences will enhance students' understanding of the concepts and have been shown to be effective strategies for adolescent learners (Barron \& Darling-Hammond, 2008; Learning Point Associates, 2005; Lickona, 2004; NCREL, 2005). Therefore, their use is essential to the ethics instruction and the learning environment in the classroom and school building should support such learning. Results from the present study show no statistical difference between means for those who took an ethics course and those who did not for various behaviors commonly held as unethical. For example, results indicate that both groups were more likely to justify unethical academic behavior in certain circumstances, as opposed to responding that unethical academic behavior is simply not justifiable. As another example, students participating in all numbers of ethics courses scored closer to "moderately unethical" than "unethical" when asked how they would rate copying a classmate's homework and rewording a published document without citation. This may indicate the need for more students to participate in an ethics course wherein the instructional strategies and learning environment in those courses to adhere to the above-referenced recommendations related to adolescent learners in the $21^{\text {st }}$ century.

For today's learners, the integration of technology enhances instruction, allows students to experience a world beyond their own classroom (Marshall, 2002; NCREL, 2005) and results in increased motivation (Falk-Ross, 2010; Hagood, 2003; NCREL, 2005), especially for at-risk students (Chandler-Olcott \& Maher, 2003). Furthermore, technology integration also results in higher student achievement (Boster, Meyer, Robert, \& Inge, 2002; Cavanaugh, Gillan, Kromrey, et.al. 2001; NCREL, 2005). Researchers identify four fundamental characteristics of how technology can enhance what and how students learn in the classroom: (1) active engagement, (2) participation in groups, (3) frequent interaction and feedback, and (4) connections to real-world contexts (Roschelle, Pea, Hoadley, Gordin, \& Means, 2000). The use of video clips in the social studies classroom serves as one example of how technology can be used to meet all four of the above-referenced characteristics. For example, students in American History class watch Glory to address the principles of responsibility, cooperation, and teamwork. Teachers provide students with a list of higher level thinking questions which they consider while watching the movie. The movie is stopped periodically to provide students time to work in groups to consider those questions. Following the movie, students work in groups to apply the aforementioned principles to conversations and projects related to the war in Iraq, a current, relevant topic for today's adolescent learners (Ethics in Education). Opportunities to incorporate video clips for student engagement abound (Annenberg Foundation). Another appropriate possibility for integrating technology for today's adolescent learners exists in the science classroom. Students studying weather can address community responsibility by creating a public service podcast to broadcast to families in their schools to help them learn how to respond in a weather emergency.

Instructional technologies are often further divided into two main categories: those students learn from and those students learn with. Those technologies from which students learn are often used effectively to supplement teacher instruction but may also be used for self-study where the computer is the main tool for delivering the instruction. For example, MedEthEx is a computer assisted instructional program integrated into a university-level bioethics course. Participants in the course who used the software demonstrated higher exam scores on selected exams and rated the course as more favorable than students whose professors utilized traditional instruction without the software program (Fleetwood, Vaught, et al, 2000). The use of similar programs should be explored by educators for use in other curricular areas or in an independent ethics course. Technological resources with which students learn are often valuable resources for promoting higher order critical thinking, creativity, and problem-solving skills, all of which are essential for ethics instruction. These technologies include but are not limited to podcasts, blogs, wikis, video-based games, digital story-telling, videoconferencing, and other multi-media resources (Annenberg Foundation; Partnership for $21^{\text {st }}$ Century Skills, 2007; NCREL, 2005).

This comprehensive school-wide ethics curriculum should extend beyond the classroom, as well. Integration in all extracurricular activities, both athletic and non-athletic, would further enhance the development of students' ethics understanding and improved the likelihood of their engagement in ethical behaviors. These extracurricular activities have been shown to have positive effects on students by teaching them positive values (Josephson Institute; Wilson, 2009). The opportunity to integrate a sense of responsibility to others is immense with the athletic extracurricular activities. In the current study, for example, students generally classified "team loafing" as only moderately unethical. Participants did not view such loafing as unethical; however, by weaving the theme of one's responsibility to a team, coaches have the opportunity to develop that definition of loafing as unethical in that 
is shows a lack of responsibility to one's teammates. Athletics may be an appropriate vehicle for addressing ethics with boys versus girls since most athletic teams are single-sex and the results of the current study indicate, in general, a number of statistically significant differences between responses of males when compared to females. An essential element of this extracurricular ethics integration includes clearly stated rules regarding the high expectations for behavior of students, parents, and faculty sponsors/coaches. Many school districts and universities require students to read, sign, and adhere to a "Code of Ethics" specifically addressing extracurricular activities. Many sponsors, too, must adhere to ethical guidelines designed specifically for their roles as coaches or activity sponsors. The ethical responsibilities focus not only on their responsibility to the individual students but to the community at large, their colleagues, and to the students' families (National AfterSchool Association, 2009). Mentoring by older students who demonstrate ethical behavior, as defined by the principles identified for a given school, is an additional and key component and can be implemented after training these youths to be effective leaders. For example, students in VIBE (Voices Involved in Promoting Black Excellence) in a suburban Philadelphia junior high school participated in a book club with elementary students in the same district. Students from both schools read the same book and then met to discuss the book and its meaning in their own lives. The goal of the VIBE group is to enhance positive self-identity and promote leadership among its students, as demonstrated by the book club experience. The collaboration continues from one school year to the next.

One model of ethics in extracurricular activities suggests that coaches and activity sponsors weave the ethics into the fabric of the group, similar to the above-referenced ethics integration across the curriculum. For example, coaches and sponsors might begin each practice/meeting with a quote from a famous person and facilitate a brief discussion of the higher level meaning of the quote and its applicability to the activity or sport in which students are currently participating, as well as its applicability to their everyday lives (Josephson Institute). Another after school program, Discovery Youth, integrates technology to have its participants create videos and other projects to teach younger students about community-related health issues, such as prevention of smoking and not using drugs (Afterschool Alliance).

When combined with a school-wide focus on a school climate that encourages the principles of ethics decided upon by the administrators, parents, students, and staff members, the curriculum is an excellent tool for promoting ethics in our adolescents. Adherence to best practices in education, such as collaboration, active student engagement, use of technology for $21^{\text {st }}$ century learners, professional development, and integration across all content areas and extracurricular activities, will allow educators to develop the ethical understandings needed to promote ethical behavior in school and beyond.

\section{CONCLUSION}

The authors have been struck by several important implications of this research. As educators, we are failing to reach enough of our secondary school students when emphasizing ethical principles. Despite the indications that our female students have higher ethical standards than male students, we have identified a gap between the expressed standards of most students and the ideals held by faculty. We expect improvements to be generated with the implementation of the integrated curriculum suggested in this research, but we also search for further causes.

This research will be followed up with an examination and identification of core ethical approaches and methods held by students. The eleven approaches under consideration include Catholic social teaching, natural law theory, consequentialism and objectivism. After determining the approaches or methods characteristic of students, we will further refine the ethics curriculum. By doing so, we hope to create a curriculum that will be meaningful to more students and provide a consistent understanding of academic ethical expectations.

\section{AUTHOR INFORMATION}

Virginia Miori, Ph.D. is an Assistant Professor at St. Joseph's University and a graduate of the LeBow College of Business at Drexel University, holding a doctoral degree in Operations Research. This research was the product of an ethics research grant from the Pedro Arrupe Ethics Center at SJU. Dr. Miori has eleven years of teaching experience and over fifteen years experience in developing and implementing statistical and operations research 
models in industry. She has received an Emerald Literati Network Award for Excellence, an Outstanding Research award from SJU and an Outstanding Dissertation award from Drexel University.

Kelly Ann Doyle, Ed.D. is the Supervisor of Communications Arts for the Abington School District in Abington, PA and an adjunct professor in the Department of Education at St. Joseph's University. Dr. Doyle earned her doctoral degree in Educational Leadership at Immaculata University and has 22 years experience in public K-12 education and has specific research interests in curriculum design and literacy development.

Kathleen Campbell is a visiting professor at St. Joseph's University and a doctoral candidate in Statistics at Temple University. Professor Campbell has 11 years of teaching experience and a strong research interest in analysis of comparisons of parameters for multiple rank order culminating in the ability to ascertain quality of test measures.

\section{REFERENCES}

1. Afterschool Alliance. After school Programs: Helping Kids Compete in Tomorrow's Workplace. http://www.afterschoolalliance.org/issue 25 tomorrow.cfm

2. Andrew, J., \& Robottom, I. (2001) Science and Ethics: Some Issues for Education. Issues and Trends. $769-780$

3. Annenberg Foundation. Ethics In America (video collection). http://www.learner.org/resources/series81.html

4. Barron, B. \& Darling-Hammond, L. (2008). Powerful Learning: Studies Show Deep Understanding Derives from Collaborative Methods. http://www.edutopia.org/inquiry-project-learning-research

5. Boster, F. J., Meyer, G. S., Roberto, A. J., \& Inge, C. C. (2002). A report on the effect of the unitedstreaming(TM) application on educational performance. Farmville, VA: Longwood University

6. Bowerman, Bruce, L., Richard T. O'Connell and Emily S. Murphree, 2011, Business Statistics in Practice 6ed., McGraw Hill/Irwin, New York, NY. pp 446-456.

7. Campbell, A. V. Chin, J., \& Voo, T.C. (2007) Medical Teacher, How can we know that ethics education produces ethical doctors? Taken from "Centre for Biomedical Ethics, Yong Loo Lin School of Medicine, National University of Singapore, Singapore". (29), 431-436.

8. Cavanaugh, C., Gillan, K., Kromrey, G., Hess, M., Blomeyer, R, (2001). The Effects of Distance Education on K-12 Student Outcomes: A Meta-Analysis. Jacksonville, FL: NCREL.

9. (http://charactercounts.org) accessed on 9/30/2010

10. Chandler-Olcott, K., \& Mahar, D. (2003). "Tech-savviness" meets multiliteracies: Exploring adolescent girls' technology-related literacy practices. Reading Research Quarterly, 38, 356-385.

11. Coughlin, S. S., Katz, W. H., \& Mattison, D. R. (1999) Ethics instruction at schools of public health in the United States. American Journal of Public Health. 89(5), 768-770.

12. Crane, A., \& Matten, D. (2004). Questioning the Domain of the Business Ethics Curriculum. Journal of Business Ethics. (54), 357-369.

13. Edgington, W. D. (2002). To promote character education, use literature for children and adolescents. The Social Studies. 93(3), May/June, 113-116.

14. Esca'meza, J., Garci'aLó peza, R., \& Jover, G. (2008). Restructuring University Degree Programmes: a New Opportunity for Ethics Education. Journal of Moral Education. 37(1), March, 41-53.

15. Ethics in Education. Movie Jigs for American History. http://www.ethicsineducation.com/movie jigs for american history.htm.

16. Falk-Ross, F. (2010). Lenses for Considering Research in New Literacies. Panel Presentation for the Annual Conference of the International Reading Association. www.reading.org/Libraries/55th.../Research_In_New_Literacies.ppt

17. Fleetwood, J., Vaught, W., Feldman, D., Gracely, E., Kassutto, Z., \& Novack, D.(2000). MedEthEx Online: A Computer-Based Learning Program in Medical Ethics and Communication Skills. Teaching and Learning in Medicine (12), 2, p. 96-104.

18. Goldie, J., Schwartz, L., McConnachie, A., Jolly, B., \& Morrison, J. (2004). Can students' reasons for choosing set answers to ethical vignettes be reliably rated? Development and testing of a method. Medical Teacher. 26(8), 713-718. 
19. Hagood, M. (2003). New media and online literacies: No age left behind. Reading Research Quarterly, 38(3), 387-391.

20. Hoge, J. D. (2002). Character education, citizenship education, and the Social Studies. The Social Studies. May/Jun, 93(3), 103-108.

21. Hurtt, K., \& Thomas, W. (2008). Implementing a Required Ethics Class for Studies in Accounting: The Texas Experience. Issues in Accounting Education, 23(1), 31-51.

22. Josephson Institute Center for Youth Ethics. Youth Activities and Tips for Schools. http://charactercounts.org/resources/activities_schools.html

23. Learning Point Associates. (2005). Using Student Engagement to Improve Adolescent Literacy. http://www.ncrel.org/litweb/adolescent/qkey10/qkey10.pdf

24. Lickona, T. (2004). Teaching respect and responsibility. CYC-Online (61). http://www.cyc-net.org/cyconline/cycol-0204-lickona.html.

25. Loepp, F.L. (1999). Models of curriculum integration. The Journal of Technology Studies(XXV), n. 2.

26. Lowry, D. (2003) An Investigation of Stduent Moral Awareness and Associated Factors in Two Cohorts of an undergraduate Business Degree in a British University: Implications for Business Ethics Curriculum design. Journal of Business Ethics. 48, 7-19.

27. Mattick, K., Bligh, J. (2006) Teaching and Assessing Medical Ethics: Where Are We Now? Journal of Medical Ethics. 32(3), March, 181-185.

28. McArthur, J. R. (2002). The why, what, and how of teaching children social skills. The Social Studies. 93(4), Jul/Aug, 183-185.

29. Milson, A. J., Wan Chu, B. (2002) Character education for cyberspace: Developing good citizens. The Social Studies. May/Jun, 93(3), 117-119.

30. Milson, A. J. (2002). Introduction: Developing a Comprehensive Approach to Character Education in Social Studies. The Social Studies. 93(3), May/Jun, 101-102.

31. Moore, K. (2008). Effective Instructional Practices: From Theory to Practice, Second edition. Thousand Oaks, CA: SAGE Publications.

32. National AfterSchool Association (2009). Code of Ethics. http://www.naaweb.org/

33. National Education Association (NEA) Education Policy and Practice Department. (2010). Global Competence Is a $21^{\text {st }}$ Century Imperative.

34. Noddings, N. (2005) Identifying and responding to needs in educations. Cambridge Journal of Education. 35(2), June, 147-159.

35. North Central Regional Educational Laboratory (NCREL). (2005). Critical Issue: Using Technology to Improve Student Achievement. http://www.ncrel.org/sdrs/areas/issues/methods/technlgy/te800.htm\#skill

36. Numminem, O., Van der Arend, A., \& Leino-Kilpi, H. (2009) Nurse Educators' and Nursing Students' Perspectives on Teaching Codes of Ethics. Nursing Ethics. 16 (1)

37. Partnership for $21^{\text {st }}$ Century Skills. (2007). Maximizing the Impact: The Pivotal Role of Technology in a $21^{\text {st }}$ Century Education System. http://www.p21.org/documents/p21setdaistepaper.pdf

38. Perkins-Gough, D. (2002). Redesigning Professional Development. Educational Leadership (59), n 6, ASCD.

39. Plaisance, P. L. (2007) An Assessment of Media Ethics Education: Course Content and the Values and Ethics. Journalism \& Mass Communication Educator, Winter, 61(4), 378-396.

40. Rabouin, M. E. (1996) Revisioning Business Ethics. Women's studies Quarterly, Fall - winter, 139-145.

41. Rhineberger-Dunn, G. M., \& Mullins, M. C. (2008). Exploring Academic Discourse on Criminal Justice Ethics: Where are We? Journal of Crime and Justice. 31(3), 81-111.

42. Rhodes, B. (2003). Ethics across the curriculum and the nature of morality: Some fundamental propositions. Teaching Ethics, Spring, 59-65.

43. Ritter, B.A. (2006). Can Business Ethics be Trained? A Study of the Ethical Decision-making Process in Business Students. Journal of Business Ethics, 68: 153-164.

44. Rodden, J. (2004). Forgiveness, Education, Public Policy: The Road Not Yet Taken. Modern Age, Fall, 333-341.

45. Ryan, P. (2003). Ethics and Resignation: A classroom exercise. Journal of Policy Analysis and Management, Spring, 22(2), 313-315.

46. The Josephson Institute Center for Youth Ethics, 2008, accessed Oct 6, 2010 http://charactercounts.org.html 
47. The Socrates Institute. The CyberEthics Project.

http://www.socratesinstitute.org/curriculum/cyberethics.html

48. $\quad$ http://thinkexist.com/quotation/if_the_children_are_untaught-their_ignorance_and/190791.html accessed on $8 / 27 / 2010$

49. http://thinkexist.com/quotes/hesiod/ accessed on 8/27/2010

50. Wilson, N. (2009). Impact of Extracurricular Activities on Students. University of Wisconsin-Stout.

51. Wright, I. (2002). Challenging students with the tools of critical thinking. The Social Studies. Nov/Dec, 257-261.

\section{NOTES}

